\title{
Analysis of Problems and Strategy for Transition and Development of Local Universities in Henan Province in Entrepreneurial Innovation
}

\author{
$\mathrm{Ke} \mathrm{Li}{ }^{1,2}$ \\ ${ }^{1}$ Luoyang Normal University, Luoyang, 471934, China \\ ${ }^{2}$ Henan key Laboratory for Big Data Processing \& Analytics of Electronic Commerce, Luoyang, \\ 471934, China
}

\begin{abstract}
Keywords: Innovation and entrepreneurship; Local colleges and universities; Transition and development; Applied talents
\end{abstract}

\begin{abstract}
In the past two years, the transformation of local colleges and universities has gradually calmed down. However, colleges and universities haven't been hesitant or slack. They are secretly mining, cultivating their own development characteristics and competitive advantages, grabbing talents, fighting research, fighting for funds, building platforms, improving reputation and ranking. As a province with a large population, a strong economy and a weak education, Henan needs to fully stimulate the vitality of innovation and entrepreneurship in colleges and universities, and improve the degree of integration and contribution of the regional and local economic and social development of colleges and universities. In order to train more high-quality applied talents in line with the needs of local economic and social development.
\end{abstract}

\section{Introduction}

In the context of mass entrepreneurship and innovation, Henan, as a province with a large population, a strong economy, and a weak education province, is faced with higher standards for higher education in the face of industrial restructuring and economic transformation and upgrading. How to stimulate the local colleges and universities to promote the vitality of innovation and entrepreneurship, promote the local colleges and universities to speed up the transformation and development, characteristic development, connotation of the development of the pace of development, to cultivate the needs of our province's economic and social development of high-quality applied talents, This is an urgent problem to be solved.

The transformation of local undergraduate colleges and universities, no matter whether it is the government, the educational administration department, the industry enterprises, or the universities themselves, has basically reached a consensus, only their starting points, demand points, specific cognition and promotion measures are different [1]. From the macro level, Under the general environment of transformation and development of the whole country and innovation, as colleges and universities that not only serve social development but also lead and serve social development, it is necessary to adjust their own development paths in a timely manner, logically speaking, Necessary.

Since 1999, in a short period of more than ten years, the conditions and environment that local colleges and universities are facing have been greatly changed. In the face of the structural contradiction of college graduates' employment and the urgent need for applied talents in the development of local economy and society, The transformation of local colleges and universities is not only a historical necessity, but also a realistic demand, but the road to the transformation and development is by no means natural, smooth, and accomplished overnight. It is full of hesitations, hesitations, wait-and-see, confusion and doubts.

The transformation is a continuous and deepening process. The current scientific and technological revolution, the rapid development of the industrial revolution, the economic structure and industrial structure of our country are in the midst of unprecedented profound changes. There is no mechanism for the integration of industry and education and the cooperation between schools and enterprises. It is difficult for colleges and universities to adapt to such changes. Institutions of higher learning, especially 
local colleges and universities, lack the ability to support innovation, and the structure of disciplines and specialties is unreasonable. The structural contradiction, such as the low quality of graduates' employment, must be solved gradually from the transformation and development, and the institutions of higher learning must create value, which is to promote the colleges and universities to create value for the economic and social development and for the development of the learners.

\section{Analysis of Prominent Problems in the Transition of Local Colleges and Universities in Henan Province}

For Henan Province, which is located in the Central Plains, in recent years, the education department of Henan Province has launched two batches of 15 pilot undergraduate colleges and universities to transform into applied technology universities, focusing on the strong demand for the development of education transformation. During this period, a mid-term inspection was conducted. In order to push the local universities to speed up the transformation, the provincial education department held an on-the-spot meeting on the construction of applied technology undergraduate colleges in Luoyang on June 2017.

Therefore, in the face of numerous policy opportunities for the country, Henan colleges and universities should be rational and conscious [2]. Speed up the pace of promoting transformation and development. One is to meet the urgent needs of national strategic needs. This is because the new pattern of economic and social development under the new normal has put forward new needs for the development of local colleges and universities. The new thinking of social reform has given birth to new rules of transformation. The new strategy of competitive development of local colleges and universities with talent intelligence resources and scale advantages requires that they speed up the transformation.

Second, the situation of Henan Province is in a period of transformation and adjustment. Especially, the inherent demand of industrial structure adjustment accelerates the rate of adjustment of the structure of talent demand. At the same time, it also changes the knowledge structure of talents, tracks, absorbs, and applies new knowledge and new technologies. The speed of popularization is quickened, especially the new pattern of park economy development in Zhengzhou Airport Comprehensive Test area and China (Henan) Free Trade Experimental Zone, which makes our province realize detour overtaking and the possibility of dislocation development become reality. This is confirmed by the scale and benefit of Henan's economic development in the "Internet era" in recent years, and the response to the demand for high-quality technical talents is more exuberant.

For a long time, due to the differences in the hierarchical status among colleges and universities, local colleges and universities have been forced to devote their energies to scientific research and academic development in order to obtain more resources. While ignoring the most important aspect of the cultivation of students' application, the students who are trained under this kind of train of thought are embarrassed that the theoretical research is not solid enough, the practical ability is not up to the needs of the practical work, In the face of this situation, more and more local colleges and universities begin to sum up and think about the ideas of running schools. In recent years, with the increase of contacts with applied universities in developed countries in the world, with the increasing frequency of communication, many local colleges and universities have a deeper understanding of applied universities.

Many local colleges and universities that undertake the task of training talents for the development of local economy and society should dare to take up the responsibility, be brave in taking responsibility, and promote reform and accelerate the transformation. It is necessary to promote development, which is the fundamental to solve the structural contradiction of employment of college graduates. Therefore, it is necessary to adhere to the orientation of "local" and "application-oriented" in the transformation and development of local undergraduate colleges and universities.

In the process of promoting the transformation and development of the pilot universities, the Provincial Education Department has regularly requested colleges and universities to sum up the experience and achievements of the transformation and development work in a timely manner, thus forming a typical demonstration effect [3]. Among them, the Huanghuai College, The Huanghe Institute 
of Science and Technology and other excellent universities have shared their experiences. However, it is not difficult to find that the problems existing in the development of local universities in Henan are still very prominent. For example, the understanding of the transformation and development is different, and the promotion measures are mostly the same. The characteristics of running a school are still not bright enough, the quality of talent training is improving slowly, the phenomenon of attaching importance to scientific research and neglecting teaching is still not greatly improved, the introduction and training of the "double teachers and two abilities" teaching staff is difficult, and the cooperation between the government, school, and enterprise is still difficult. The synergy between industry, university and research is not obvious. Although stakeholders already know these problems, it is still difficult to carry them out.

First, the obstacles encountered at the school level, such as ideological obstacles, the lag in professional construction, the ossification of the training model of talents, the serious shortage of teachers with "double teachers and two abilities", the vain cooperation between production, teaching and research, etc. The second is the difficult problem that the government is facing at the level of government. For example, the government has a strong sense of leadership, insufficient devolution of power, limited supervision and restriction, lack of protection of relevant laws and policies, and insufficient administration by law. Third, insufficient protection of funds and resources is difficult to meet the needs of the rapid expansion of the scale of local colleges and universities. Many colleges and universities lack not only the advantage and ability of resource acquisition, but also the functional foundation of self-hematopoiesis.

Especially under the background of "new normal" and supply-side structural reform, the society demands the transformation of colleges and universities more urgently. The resources of high-quality higher education in Henan Province are very scarce, and the masses and all walks of life have ardent expectations for local colleges and universities. However, it often criticizes the talent cultivation, social service and innovation leading of local colleges and universities, which can be said to be love and hate.

\section{The Strategy Analysis of the Transition of local Universities in Henan under the Background of Innovation and Entrepreneurship}

Huanghuai University, Xuchang College, Yellow River Science and Technology College, Zhoukou normal College, Shangqiu normal College, especially prominent, It is because of the decision makers of these schools and their main managers that the participants have formed a broad, unified understanding, set clear and firm goals, together with effective measures and strong implementation, and have developed after nearly five years of reform and development. In the process of transformation, we should innovate the construction of curriculum system, reform and transform the basic specialty, connect with the market, and highlight the practicability and professionalism.

In this respect, the College of Electronic Commerce of Luoyang normal University has carried out bold exploration and practice. Through cooperation with a certain enterprise in Beijing, it has introduced a standard system of training qualified personnel for e-commerce professional posts in the National Engineering Laboratory of Electronic Commerce Trading Technology. To establish the "11 N" cooperation mode between schools and enterprises, to create a new talent training system of "205.51", to introduce the full-time front-line trainers of enterprises in the third grade of undergraduate courses, to replace the courses of professional skills, and to carry out stage teaching and project practice teaching. The exploration of flipping classroom, team training, formative evaluation, establishing micro-credit, has made the reform effect quickly, and improved the quality of training applied talents of electronic commerce specialty.

The government should become the policy guarantee and resource support for the transformation of local colleges and universities, urge the instructor to regulate the government behavior, bring the transformation and development of colleges and universities into the legal track, and establish the corresponding mechanism of investigation and accountability for the educational reform. In order to reduce the arbitrariness and subjective judgment of decision-making, to establish service-oriented government, to change the idea of "control", to embody "service" in all aspects of work, and to create a 
good legal system for the transformation and development of local colleges and universities. Policy and social environment, help, encourage, support and guide local colleges and universities to establish close ties with local enterprises and industries in the process of transformation and development) increase financial support and improve supervision mechanisms. We should also prevent colleges and universities from breaking up the east wall and replenishing the west wall, which will be used as funds for transformation and development.

On the one hand, the government should take the lead, lead by the government, promote the cooperation between the enterprises and the universities, and realize the complementary advantages. On the other hand, the enterprises themselves actively participate in the curriculum construction, personnel training and teacher training in colleges and universities, so as to avoid the cooperation between schools and enterprises becoming a contract without substantial progress.

Do a good job of supervision by public opinion. Actively establish a think tank for educational development. Encourage qualified and competent social organizations to set up third-party evaluation institutions to participate in the training of talents in colleges and universities, professional evaluation, and evaluation of transformation and development. Graduate employment entrepreneurship and development ability evaluation and so on process comes.

Establish a new model of talent training. Luoyang normal College, Nanyang Institute of Technology, Shangqiu normal College, etc., have explored a new model and path. To set up a high level "double-teacher and dual-ability" teacher team, we should change the rigid recruitment system, break the internal system of difficult sharing and mobility of teachers, actively broaden the channels of teachers' sources, and not only introduce some innovative abilities, Talents with high academic qualifications with strong scientific research ability should also introduce experienced and excellent technicians and managers to serve as part-time teachers and establish a "double-teacher and dual-ability" team with high teaching level and strong practical ability.

Set up multi-dimensional evaluation system, evaluate teachers in all directions, in the aspects of teacher performance appraisal, professional title evaluation, study abroad, go out training and so on, tilt to "double teachers and two ability type" teachers, ensure their good career development channel. Stimulate the internal motivation of teachers, improve the enthusiasm and enthusiasm of the work..

We must constantly promote the strategic alliance in the areas of deep cooperation between schools and enterprises, joint construction of resources sharing, project development, and transformation of achievements. We must also improve the long-term mechanism of cooperation between schools and enterprises, and build a service system oriented to industry enterprises, so as to serve the enterprises. The market trains talents for scientific and technological innovation.

\section{Summary}

As a province with a large population, a strong economy and a weak education, Henan needs to fully stimulate the vitality of innovation and entrepreneurship in colleges and universities, and improve the degree of integration and contribution of the regional and local economic and social development of colleges and universities. In order to train more high-quality applied talents in line with the needs of local economic and social development.

First, to strengthen the top-level design, to unify the thinking and understanding of the transformation of local colleges and universities, and to formulate specific implementation plans; second, to persist in classified management and guidance, to persist in doing something, to avoid "one-size-fits-all"; and third, to urge local colleges and universities to make independent choices. To give full play to the role of market regulation and competition; fourth, to strengthen policy protection and effectively stimulate the motive force and driving force of school transformation; fifthly, to strengthen supervision and guidance, to focus on promoting reform through transformation, to promote implementation by supervision and inspection, to promote development by action, and to refrain from formalism. Enforcement is weak. 


\section{Acknowledgements}

This paper is supported by Henan key Laboratory for Big Data Processing \& Analytics of Electronic Commerce, and also supported by the bidding subject of Henan provincial government decision research (2016B215), the key Scientific Research Project Plan of Henan Province (17A880020) and the project of supporting young backbone teachers in colleges and universities in Henan province (2013GGJS).

\section{References}

[1] Zhao Zhongjian, Zhuo Zelin. Creating an innovative and Entrepreneurial University: a report from the US Department of Commerce. Shanghai: Shanghai Century Publishing Co., Ltd. 2016.

[2] Wang Chengxu. Establishing Entrepreneurial University: the way of organizational Transformation, Beijing: people's Education Press 2003.

[3] Chen Jin, Sheng Weizhong. Innovative Universities: changing the genes of higher Education. Beijing: Tsinghua University Press, 2017. 